\title{
Effectiveness and Safety of Autologous Fat Transfer in Various Treatment Protocols
}

Citation for published version (APA):

Groen, J-W. (2018). Effectiveness and Safety of Autologous Fat Transfer in Various Treatment Protocols. [Doctoral Thesis, Maastricht University]. Datawyse / Universitaire Pers Maastricht. https://doi.org/10.26481/dis.20180412jg

Document status and date:

Published: 01/01/2018

DOI:

10.26481/dis.20180412jg

Document Version:

Publisher's PDF, also known as Version of record

\section{Please check the document version of this publication:}

- A submitted manuscript is the version of the article upon submission and before peer-review. There can be important differences between the submitted version and the official published version of record.

People interested in the research are advised to contact the author for the final version of the publication, or visit the DOI to the publisher's website.

- The final author version and the galley proof are versions of the publication after peer review.

- The final published version features the final layout of the paper including the volume, issue and page numbers.

Link to publication

\footnotetext{
General rights rights.

- You may freely distribute the URL identifying the publication in the public portal. please follow below link for the End User Agreement:

www.umlib.nl/taverne-license

Take down policy

If you believe that this document breaches copyright please contact us at:

repository@maastrichtuniversity.nl

providing details and we will investigate your claim.
}

Copyright and moral rights for the publications made accessible in the public portal are retained by the authors and/or other copyright owners and it is a condition of accessing publications that users recognise and abide by the legal requirements associated with these

- Users may download and print one copy of any publication from the public portal for the purpose of private study or research.

- You may not further distribute the material or use it for any profit-making activity or commercial gain

If the publication is distributed under the terms of Article $25 \mathrm{fa}$ of the Dutch Copyright Act, indicated by the "Taverne" license above, 


\section{Summary}

Chapter 1 is a general introduction to autologous fat transplantation (AFT) and the topics in this thesis. This chapter forms the background against which the aims and research questions are explained

Chapter $\mathbf{2}$ is a meta-analysis, that gives an overview of the efficacy and safety of the use of AFT in onco-plastic breast reconstruction. In this chapter the results from 43 studies are reported in terms of indication, volume retention and patient-/ surgeon satisfaction. Furthermore, safety of the procedure is reported in terms of the oncological- and radiological safety besides the complication rate. Loco-regional and distant oncological recurrence in patients who underwent breast reconstruction in conjunction with AFT were 2.5 and $2.0 \%$ respectively, which is considered lower than that following similar procedures without AFT. The total complication rate of $8.4 \%$ is also considered lower than other forms of breast reconstruction and radiological findings after AFT are easily distinguished from other pathology. There was however a higher rate of biopsies based on radiological findings following AFT all of which were benign. Patient- and surgeon satisfaction was considered high and the mean volume retention of $76.8 \%$ seems promising.

Chapter $\mathbf{3}$ is a succeeding systematic review that further elaborates on the efficacy and safety of AFT in conjunction with breast augmentation for cosmetic purposes. Twenty-two articles, covering a total of 3565 patients with a follow-up of 12 to 136 months reported a total complication rate of $17.2 \%$. Complications most frequently comprised of indurations, persistent pain or hematomas and mammograms revealed micro- or macrocalcifications in $9 \%$ and $7 \%$ respectively. Calcifications were however, still easily distinguished from those that can be found in breast cancer and the mean volume retention was $62.4 \%$. Patient- and surgeon satisfaction was considered high.

Chapter 4 gives an overview of the applications of AFT in the treatment of scars. In a systematic review of 26 articles a significant improvement of scar appearance, skin characteristics and pain was reported. Subsequently, an improving trend of itch, volume restoration and three-dimensional contour was found. However, no meta-analysis could be performed due to heterogeneity between studies in methodology as well as reporting outcomes. 
Chapter 5 contains a reply to a letter to the editor, further elaborating on the positive effects of AFT on scar tissue and scar-related conditions. Herein, we further discussed the extend of the AFT possibilities for different types of scar tissue (i.e. Morbus Dupuytren) as well as hypotheses regarding the mechanisms through which the positive effects of AFT are orchestrated. Finally, we discussed the difficulties with reimbursement from insurance companies and an upcoming Dutch, multicenter, RCT comparing external preexpansion and AFT versus the conventional tissue-expander/ implant-based breast reconstruction in mastectomy patients.

In Chapter 6 the authors elaborated on the subject of oncological safety by comparing results from clinical studies with the outcomes of 35 basic science studies. What stood out were the significant discrepancies between results from clinical studies declaring the relative safety of AFT and the results from the basic science studies. The latter comprised mainly of studies that co-cultured different breast cancer cell lines in-vitro or in-vivo (mouse models) with ADSCs from lipoaspirate and reported on the different pathways through which tumor growth, -progression or metastasis were orchestrated. One of the main culprits in the comparison of the results from clinical and basic science studies originate in the significant differences in cell-biological environment between cultured laboratory- and clinical "real life" settings. Therefore, both specific subgroup analysis in clinical studies as well as better real-life simulating laboratory settings in basic science studies are needed to make conclusive statements about the oncological safety of AFT.

Chapter 7 investigates the AFT experience, -techniques used and -opinions of 358 plastic/ breast surgeons from 10 European countries. In this survey study it was shown that breast surgery is still the most prominent indication for which AFT is used by plastic surgeons, and that most adhere to the Coleman Method. However, deviations thereof are becoming more apparent, with for example the liposuction device instead of manual aspiration for harvesting of the fat, used in $41.9 \%$ of overall respondents. Furthermore, it was shown that intraglandular AFT is still performed in both implant- as well as flap based breast reconstruction besides local defect corrections, such as after lumpectomy. Given the uncertainties that still exists regarding the oncological safety of AFT and the fact that current clinical guidelines advice against intraglandular fat injection the authors argued that further surgeon education on this subject might be beneficial. 
Chapter 8 further elaborates on the experience from surgeons and patients with AFT by comparing the cosmetic appreciation of different groups from both. European surgeons and Dutch patients following both DIEP as well as augmentation procedures of the breast (besides a control group), were asked to evaluate pre-/ postoperative photographs of BRAVA + AFT for various indications. The interrater agreements that were found between groups varied from high (between surgeons and patient groups mutually) to very low (surgeons vs augmentation patients). In order to further improve doctor-patient communications future studies should focus more on the etiology of these different consensuses and disparities, with emphasis on the qualitative characteristics thereof.

Chapter 9, concludes the thesis with the investigation of another upcoming indication of AFT, namely its use in facial rejuvenation. Through a systematic review with meta-analysis of 18 articles, covering 3073 patients the authors found that the procedure is generally met with few complications and high patients satisfaction rates. Furthermore, certain filler specific complications like hypersensitivity reactions and granuloma formation are unlikely, due to the biocompatible nature of AFT. However, larger cohort studies are needed before the same can be said about more operator dependent major complications like skin necrosis and thrombo-embolic events.

Chapter 10, entails the general discussion, in which the results that were presented in this thesis are discussed in the light of the current scientific literature. 